\title{
Profile and Treatment Outcomes of Filipino Multiple Myeloma Patients Managed at a Tertiary Institution: A Single Center Six-Year Retrospective Study
}

\author{
\$ \\ Joy Ann V. de Castro, MD \\ Flordeluna Z. Mesina, MD \\ Priscilla B. Caguioa, MD
}

\section{ABSTRACT}

Introduction: Multiple myeloma remains to be an incurable hematologic entity, but with the advent of novel agents more patients experience significantly longer survival. In a third world country like the Philippines, autologous bone marrow transplant after chemotherapy for newly diagnosed cases which is the standard of care is difficult to comply. The management paradigm for myeloma has shifted over the years, hence this study.

Objective: Determine the clinical profile and treatment outcome of Filipino multiple myeloma patients diagnosed and managed at a tertiary institution from January 2013 to December 2018.

Methodology: Retrospective, observational and cross-sectional study of eligible symptomatic myeloma patients.

Results: Data for six years were retrospectively collected from a single tertiary institution. The clinical characteristics at diagnosis, treatment and survival rates of 109 active myeloma patients were described. The median age was 61 years (range, 28-83), with $51.4 \%$ being female. Median overall

Joy Ann de Castro

joyous_angel2001@yahoo.com

Section of Clinical Hematology, Department of Medicine University of Santo Tomas Hospital Manila, Philippines survival was 49.5 months $(95 \% \mathrm{Cl} 42.7-56.2)$. The frontline treatments of patients were also analyzed. The combined deep response (complete and very good partial) of our patients at $31.7 \%$ was higher than of Asian Myeloma Network Study at 30.9\%. None of them yet underwent autologous bone marrow transplantation as of date. Novel agents, especially bortezomib was used in $35.7 \%$ and significantly affected overall and progression-free survivals when used as a first line treatment.

Conclusion: This retrospective analysis demonstrated the paradigm shift in the treatment modality of myeloma and the survival outcomes has significantly improved, especially on the best response to chemotherapy. Short of the ideal management in a third world country like the Philippines, we can now set our new standard of care based on the treatments available including novel agents like bortezomib, and the best practices that our institution offers.

Keywords: Multiple Myeloma, Profile, Outcomes, Tertiary

\section{INTRODUCTION}

Multiple Myeloma (MM) is a malignancy of the terminal differentiation of $B$ cells, associated with 
production of increased amounts of immunoglobulin. [1] The clinical presentation is diverse, ranging from hypercalcemia, elevated creatinine level (renal involvement), anemia, bone pains, or a combination of these collectively referred to as CRAB. The disease is further defined as symptomatic or active.[1] MM is diagnosed based on the results of bone marrow biopsy and serum protein electrophoresis (SPEP) and/or urine protein electrophoresis (UPEP). Biopsy of any soft tissue mass is also helpful in detecting plasmacytoma, which is composed of plasma cell accumulation. Serum-free light chain (sFLC) analysis is also now recommended as part of the initial workup for patients suspected of having MM.[2] The International Myeloma Working Group (IMWG) defines the diagnostic criteria for active multiple myeloma. [3] (see Appendix A). The Durie Salmon System [4] or the International Staging System [5] (ISS) is used for grading and prognostication of the disease (see Appendix B).

Despite the advances in treatment, MM remains to be an incurable condition, but with the advent of novel agents, more patients now experience survival way beyond three years.[6] The first step in management is to determine whether a patient is eligible for bone marrow transplant (BMT) or not. [2] For those eligible, autologous bone marrow transplant (auto-BMT) after chemotherapy is the standard of care for newly diagnosed MM.[2] For those transplants ineligible, melphalan-based regimen is given preferably with a proteosomeinhibitor bortezomib. The most robust data for bortezomib among newly diagnosed $M M$ who are transplant ineligible came from the VISTA study (Velcade as Initial Standard Therapy in Multiple Myeloma: Assessment With Melphalan and Prednisone) which demonstrated superior progression-free survival (PFS) and overall survival (OS) for patients who were given the drug with melphalan and prednisone when compared with melphalan and prednisone alone.[7]

In 2006, Caguioa et al. through the Philippine Society of Hematology and Blood Transfusion made a cross-sectional study that described the characteristics and outcome of patients diagnosed with $M M$ in the Philippines. Among the 278 patients in this study, $87 \%$ received melphalan-prednisone as the first line treatment; and among those who received the first line regimen, only $2.5 \%$ attained complete response.[8] The management paradigm for Filipino MM cases has shifted since then; hence the creation of this study.

The general objective of this paper is to determine the clinical profile and treatment outcome of Filipino MM patients diagnosed and managed at a tertiary institution (University of Santo Tomas Hospital or USTH) from January 2013 until December 2018. Specifically, it aims to (1) characterize the demographic and clinical characteristics of patients diagnosed with $M M$; (2) describe the management and treatment outcomes; (3) determine survival endpoints such as median survival, overall survival, progression-free survival and time to relapse; and (4) identify long-term treatment side effects, such as cardiotoxicity, pulmonary fibrosis and infertility, and incidence of secondary malignancy.

\section{METHODOLOGY}

This retrospective, observational and cross-sectional study involved patients with $M M$ diagnosed from January 2013 up to December 2018 (six years). Data of patients were extracted from the developed secured system or database of the Philippine Lymphoma and Myeloma Registry and Benavides Cancer Institute.

All adult Filipino patients aged $>18$ years diagnosed with $M M$ in the participating tertiary institution (USTH) from January 1, 2013 until December 31, 2018 were included in this study. Patients diagnosed with plasma cell disorders other than MM were excluded.

No formal sample size calculation was required in this review. All MM patients who fulfill the inclusion criteria were counted.

The investigators utilized and maximized the database of the Philippine Lymphoma and Myeloma Registry with that of the Benavides Cancer Institute. The following data were covered: demographics (median age at diagnosis, gender, occupation, area of residence [spent $>/=20$ years], highest educational attainment); medical history (comorbid illness, list of medications, past medical history); clinical characteristics (presenting symptoms, type of biopsy, site of biopsy, International Prognostic Staging System [IPSS], median hemoglobin at diagnosis, median creatinine at diagnosis, median ionized calcium at diagnosis, serum heavy and light chains, presence of lytic bone disease and/or fractures at diagnosis, fluorescent in situ hybridization 
[FISH]/cytogenetics); and treatments received (date of initiation of treatment, chemotherapy regimen used, number of cycles of chemotherapy, need for radiation therapy).

The following parameters regarding treatment outcome and survival were also included: outcomes of treatment (tumor response, type of second line treatment, response to second line treatment, subsequent lines of treatment, response to subsequent lines of treatment, second primary tumor, other long-term side effects [ie, cardiotoxicity, infertility, pulmonary fibrosis]; and cause of death, if applicable.

The IMWG criteria for tumor response [9] was used to define treatment outcomes for patients diagnosed with MM (see Appendix C).

\section{Data Analysis}

Continuous variables were summarized by providing the mean, median and standard deviation. Categorical variables were presented as frequency and percentages. The Kaplan-Meier method of survival analysis was used to determine the overall and progression-free survival reported in this study as median survival in months. Overall survival (OS) was determined by looking at the length of time from the date of diagnosis (same as start of treatment in these cases) to death. Median survival reflected the length of time from the date of diagnosis (and start of treatment) that half of the patients were still alive.[10] Progression-free survival (PFS) was measured from the time of treatment initiation to disease progression or death from any cause. Time to relapse (TTR) is defined as the time elapsed from the date of stable status or better to disease progression status or death. To compare the difference in survival distributions of two groups, Log-rank tests were used. A p-value less than 0.05 was considered to be statistically significant. [1 1] Analyses were done using the Statistical Package for the Social Sciences version 16.

\section{Ethical Considerations}

This study was approved by the hospital Institutional Review Board (IRB) on September 20, 2018. A letter of permission from the Medical Director and the Chair of the Benavides Cancer Institute were secured. Every patient included was ensured anonymity and handled with full observance of the data privacy act. The primary investigator does not have any conflict of interest and has nothing to disclose.

\section{RESULTS}

\section{Patient and Treatment Demographics}

One hundred nine participants (109) were included in this retrospective analysis. One patient was excluded being a case of smoldering myeloma. Demographics and baseline clinical characteristics are reflected in Table 1. The median age of diagnosis was 61 years (range of 28 to 83 years) and $51.4 \%$ were females (56 out of 109 participants). Based on the IPSS at diagnosis, $21.1 \%$ were stage III but majority were still unknown at $44.9 \%$. Also at the time of diagnosis, hemoglobin, creatinine and ionized calcium were at median level of $9.5 \mathrm{~g} / \mathrm{L}$ (range of 5.0 to 15.2$), 1.13 \mathrm{mg} / \mathrm{dL}(0.4$ to 8.07 ) and $1.28 \mathrm{mmol} / \mathrm{L}(0.9$ to 2.85$)$, respectively. The majority had unknown serum-free heavy and light chain status, though those who were able to comply predominantly had $\lg G$ at $10.1 \%$ and lambda at $21.1 \%$. Lytic bone disease and/or fractures at diagnosis were noted to be at $81.7 \%$, 156 of this were detected by simple $x$-ray or skeletal survey $[62.9 \%$ out of total with pathognomonic bone lesions]). FISH and/or cytogenetic data were only available in 28 out of 109 (25.7\%) patients: $17.4 \%$ (19), 3.7\% (4) and $4.6 \%(5)$ were standard, intermediate and high risk, respectively.

Other pertinent patient information was profiled. At the time of diagnosis, $33.9 \%$ of patients (37 of 109) were employed and $66.1 \%$ (72 of 109) were unemployed (or already retired), $84.7 \% \quad$ (61 of 72) of which were professionals (attained college degree) on their respective fields prior to age 60. Most of the respondents were metropolitan-based for the past 20 years at $72.0 \%$, with $28.0 \%$ living in the rural areas and had exposure to farming.

In terms of comorbidity, $50.5 \%$ (55 of 109) of patients did not have, $30.2 \%$ (33 of 109) had one and 19.3\% (21 of 109) had multiple preexisting conditions. Hypertension was the topmost at $40.4 \%$ and patients' medications mostly were antihypertensive with antiplatelet aspirin.

All of the patients in this study underwent bone marrow aspiration biopsy at the posterior superior iliac spine. 
Table 1. Multiple myeloma patient demographics and baseline clinical characteristics

\begin{tabular}{|c|c|c|}
\hline Factor & $\begin{array}{c}\text { Number } \\
\text { (total }=109 \text { ) }\end{array}$ & Percentage (\%) \\
\hline Age in years & 61 years old $(28-83)$ & \\
\hline \multicolumn{3}{|l|}{ Gender } \\
\hline Male & 53 & 48.6 \\
\hline Female & 56 & 51.4 \\
\hline \multicolumn{3}{|c|}{ International Prognostic Staging System } \\
\hline Stage I & 16 & 14.7 \\
\hline Stage II & 21 & 19.3 \\
\hline Stage III & 23 & 21.1 \\
\hline Unknown & 49 & 44.9 \\
\hline Hemoglobin, g/dL & $9.5(5.0-15.2)$ & \\
\hline Serum creatinine, $\mathrm{mg} / \mathrm{dL}$ & $1.13(0.4-8.07)$ & \\
\hline lonized calcium, mmol/L & $1.28(0.9-2.85)$ & \\
\hline \multicolumn{3}{|l|}{ Serum heavy chain } \\
\hline $\lg G$ & 11 & 10.1 \\
\hline $\lg A$ & 5 & 4.6 \\
\hline $\lg M$ & 3 & 2.7 \\
\hline Unknown & 90 & 82.6 \\
\hline \multicolumn{3}{|l|}{ Serum light chain } \\
\hline Kappa & 15 & 13.8 \\
\hline Lambda & 23 & 21.1 \\
\hline Unknown & 71 & 65.1 \\
\hline \multicolumn{3}{|c|}{ Lytic bone disease and/or fractures at diagnosis } \\
\hline Present & 89 & 81.7 \\
\hline Absent & 14 & 12.8 \\
\hline Unknown & 6 & 5.5 \\
\hline \multicolumn{3}{|l|}{ FISH and/or cytogenetics } \\
\hline Standard Risk & 19 & 17.4 \\
\hline Intermediate Risk & 4 & 3.7 \\
\hline High Risk & 5 & 4.6 \\
\hline Unknown & 81 & 74.3 \\
\hline
\end{tabular}

*Values are either median at diagnosis (range), or frequency (\% frequency)

Patients' management and treatment demographics are shown in Table 2. As soon as the diagnosis of myeloma was confirmed at least by bone marrow morphology, treatment was immediately administered either by single or dual oral regimen. Due to financial challenges and limited resources, most of the patients included were managed pharmacologically.

In the frontline setting, $23.5 \%$ of patients still received the combination of melphalan-prednisone-thalidomide.
A number of patients at $35.7 \%$ and $2.04 \%$ had a regimen containing proteosome-inhibitor bortezomib and newer immuno-modulator lenalidomide, respectively. All the frontline treatments contained steroids, either dexamethasone or prednisone. Eleven (11) patients did not initiate treatment at our institution or opted to be endorsed back to their hometown hematologist, or lost to follow-up.

During the patients' second line treatment, $44.5 \%, 11.1 \%$ and $7.4 \%$ received a regimen 
Table 2. Multiple myeloma management and treatment demographics

\begin{tabular}{|c|c|c|c|c|}
\hline Regimen & $\begin{array}{l}\text { Frontline } \\
\text { Treatment }\end{array}$ & $\begin{array}{l}\text { Second } \\
\text { Treatment }\end{array}$ & $\begin{array}{l}\text { Third } \\
\text { Treatment }\end{array}$ & $\begin{array}{l}\text { Fourth Treatment } \\
\text { and more }\end{array}$ \\
\hline Oral steroid alone (Dexa or Pred) & $3.1 \%(3)$ & 0 & 0 & 0 \\
\hline $\begin{array}{l}\text { Immuno-modulator }+ \text { Steroid } \\
\text { (Thal-Dexa or Len-Dexa) }\end{array}$ & $20.4 \%(20)$ & $29.6 \%(8)$ & $13.3 \%(2)$ & 0 \\
\hline $\begin{array}{l}\text { Oral alkylating agent + Steroid } \\
\text { (MP) }\end{array}$ & $17.3 \%(17)$ & 0 & 0 & $10.0 \%(1)$ \\
\hline Proteasome inhibitor + Steroid (VD) & $15.3 \%(15)$ & $7.4 \%(2)$ & $20.0 \%(3)$ & 0 \\
\hline $\begin{array}{l}\text { Oral alkylating agent + Steroids + } \\
\text { Immunomodulator (MPT) }\end{array}$ & $23.5 \%(23)$ & $18.5 \%(5)$ & $13.3 \%(2)$ & 0 \\
\hline $\begin{array}{l}\text { Proteasome inhibitor + Steroid + } \\
\text { Immunomodulator (VDT) }\end{array}$ & $11.2 \%(11)$ & $26.0 \%(7)$ & $13.3 \%(2)$ & $20.0 \%(2)$ \\
\hline $\begin{array}{l}\text { Proteasome inhibitor + Alkylating } \\
\text { agent + Steroid (VMP) }\end{array}$ & $8.2 \%(8)$ & $7.4 \%(2)$ & $6.7 \%(1)$ & 0 \\
\hline $\begin{array}{l}\text { Single agent newer alkylating } \\
\text { agent (bendamustine) }\end{array}$ & 0 & $3.7 \%(1)$ & $6.7 \%(1)$ & 0 \\
\hline $\begin{array}{l}\text { Alkylating agent + Proteasome } \\
\text { inhibitor + Steroid (CyBorD) }\end{array}$ & $1.0 \%(1)$ & 0 & 0 & $10.0 \%(1)$ \\
\hline $\begin{array}{l}\text { Vinca Alkaloid + Anthracycline + } \\
\text { Steroids (VAD) }\end{array}$ & 0 & $3.7 \%(1)$ & 0 & 0 \\
\hline $\begin{array}{l}\text { Newer alkylating agent + } \\
\text { Proteasome inhibitor + Steroid (BVD) }\end{array}$ & 0 & 0 & $6.7 \%(1)$ & $10.0 \%(1)$ \\
\hline $\begin{array}{l}\text { Newer Immunomodulator + } \\
\text { Proteasome inhibitor + Steroid (RVD) }\end{array}$ & 0 & $3.7 \%(1)$ & $20.0 \%(3)$ & $50.0 \%(5)$ \\
\hline Total Treatment & 98 & 27 & 15 & 10 \\
\hline
\end{tabular}

\section{Legend:}

Dexa: Dexamethasone

Pred: Prednisone

Thal-Dexa: Thalidomide-Dexamethasone

Len-Dexa: Lenalidomide-Dexamethasone

MP: Melphalan-Prednisone

VAD: Vincristine-Doxorubicin-Dexamethasone

RVD: Lenalidomide-Bortezomib-Dexamethasone
VD: Bortezomib-Dexamethasone MPT: Melphalan-Prednisone-Thalidomide VDT: Bortezomib-Dexamethasone-Thalidomide VMP: Bortezomib-Melphalan-Prednisone CyBorD: Cyclophosphamide-Bortezomib-Dexamethasone BVD: Bendamustine-Bortezomib-Dexamethasone containing bortezomib, lenalidomide and newer alkylating agent bendamustine, respectively. In this setting, 96.3\% received steroids. On their third line treatment, $66.7 \%, 26.7 \%$ and $26.7 \%$ had chemotherapy containing bortezomib, lenalidomide and bendamustine, respectively; and $93.3 \%$ were given steroids. Among all subsequent treatments (fourth line and beyond), 90.0\%, 50.0\% and $50.0 \%$ had chemotherapy containing bortezomib, lenalidomide and bendamustine, respectively; and $90.0 \%$ had steroids.

A total of $9.17 \%$ of patients underwent radiation therapy either for palliation of pain due to severe spinal cord compression or presence of plasmacytoma. As of date, none of the patients included went through autologous bone marrow transplantation due to limited personal resources.
Table 3 summarizes the outcome or response to treatment of all our myeloma patients. Majority were able to comply with the prescribed number of cycles of their respective chemotherapy protocol and by practice follow-up for evaluation were done prior to the next treatment schedule, devoid of complications in between.

After the first treatment, $18.4 \%$ and $13.3 \%$ achieved complete response (CR) and very good partial response (VGPR), respectively. From these, $66.7 \%$ of CR and $71.4 \%$ of VGPR received bortezomib as part of their induction regimen. Overall response rate (ORR) was $40.9 \%, 27.6 \%$ had progressive disease (PD) and $24.4 \%$ expired on frontline management. The most common cause of demise was septicemia. As at the time of writing, $29.4 \%$ were on maintenance treatment. 
Table 3. Multiple myeloma response rates to treatment

\begin{tabular}{lcccc}
\hline & $\begin{array}{c}\text { First treatment } \\
(\mathbf{n = 9 8 )}\end{array}$ & $\begin{array}{c}\text { Second Treatment } \\
(\mathbf{n = 2 7})\end{array}$ & $\begin{array}{c}\text { Third Treatment } \\
(\mathbf{n = 1 5})\end{array}$ & $\begin{array}{c}\text { Fourth Treatment and } \\
\text { more }(\mathbf{n = 1 0})\end{array}$ \\
\hline Complete Response & $18.4 \%(18)$ & $11.2 \%(3)$ & $6.7 \%(1)$ & 0 \\
Very Good Partial & $13.3 \%(13)$ & $18.5 \%(5)$ & $13.3 \%(2)$ & $30.0 \%(3)$ \\
Response & $9.2 \%(9)$ & $7.4 \%(2)$ & $\mathbf{6 . 7 \% ( 1 )}$ & $10.0 \%(1)$ \\
Partial Response & $7.1 \%(7)$ & $\mathbf{3 7 . 0 \% ( 1 0 )}$ & $\mathbf{4 6 . 7 \% ( 7 )}$ & 0 \\
Stable Disease & $\mathbf{2 7 . 6 \% ( 2 7 )}$ & $\mathbf{2 2 . 2 \% ( 6 )}$ & $\mathbf{1 3 . 3 \% ( 2 )}$ & $10.0 \%(1)$ \\
Progressive Disease & $24.4 \%(24)$ & $3.7 \%(1)$ & $13.3 \%(2)$ & $50.0 \%(5)$ \\
Expired & &
\end{tabular}

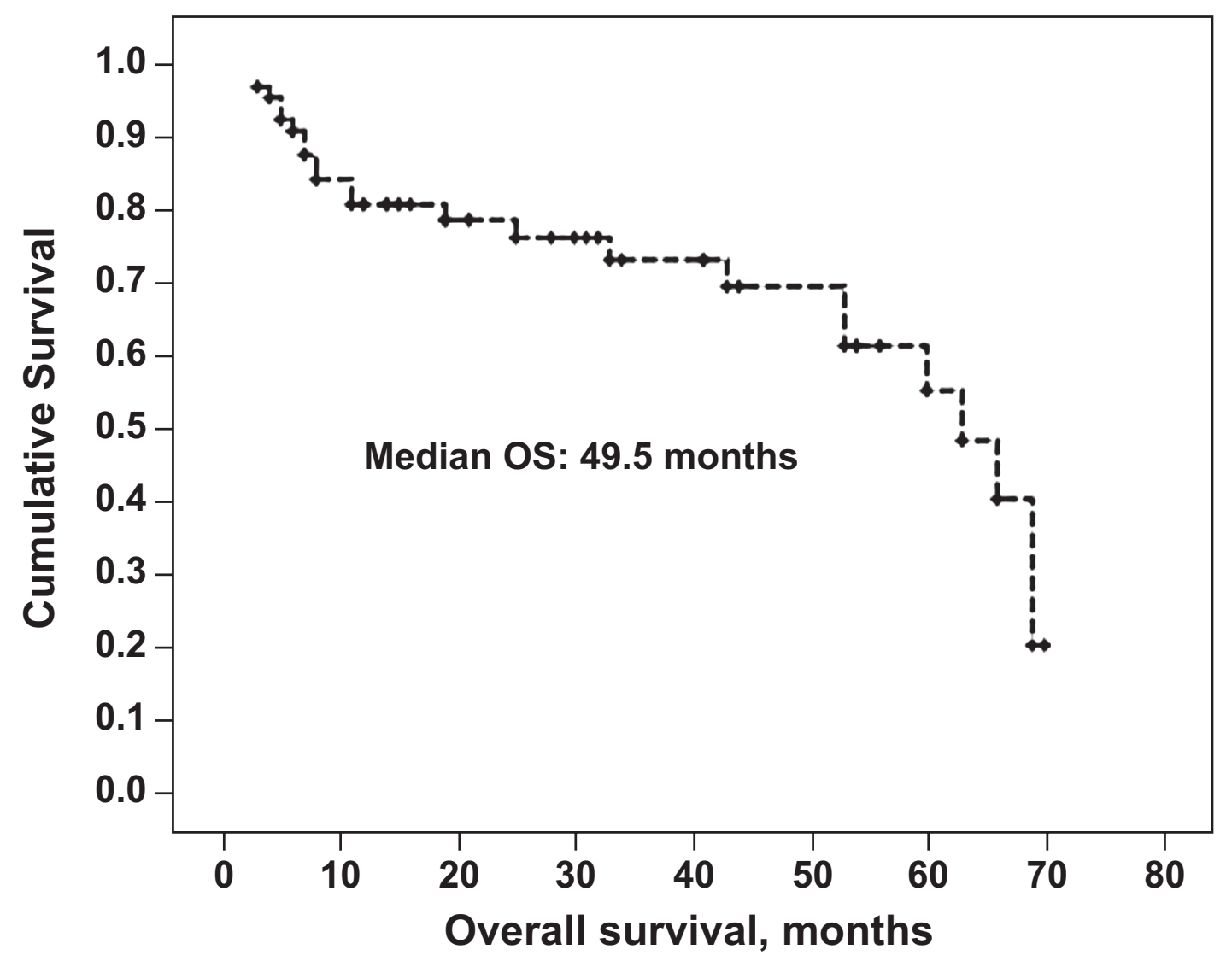

Figure 1. Overall survival in months of Filipino multiple myeloma patients in the USTH. Generally, the length of time from the date of diagnosis and treatment initiation to death is almost 4.1 years.

Subsequent to the second treatment, $11.2 \%$ and $18.5 \%$ attained CR and VGPR respectively; ORR was $37.1 \%$ versus $22.2 \%$ who progressed; $24.2 \%$ on maintenance treatment; and only $3.7 \%$ died. At the end of the third treatment, $6.7 \%$ and $13.3 \%$ had CR and VGPR, respectively; ORR was $26.7 \%$ and $13.3 \%$ progressed, $18.8 \%$ were on maintenance treatment and $13.3 \%$ deceased. After the fourth and succeeding treatment, the best response achieved was VGPR at $30.0 \%$; only $10 \%$ was ongoing maintenance therapy; $10.0 \%$ had PD and $50.0 \%$ succumbed to death.
Figure 1 shows the OS of all myeloma patients in our institution for the period of six years. Median OS was 49.5 months (at $95 \% \mathrm{Cl}$ : range of 42.7 to 56.2 months).

Figure 2 reflects that the median PFS of patients included was 25.0 months $195 \% \mathrm{Cl}$ : 3 to 50.8 months). In terms of regimen, patients had median PFS of 50.3 months (95\% Cl: 39.8 to 60.7 months) after the first treatment with bortezomib-containing regimen versus median PFS of 28.7 months $195 \%$ Cl: 21.8 to 35.6 months) without bortezomib; and median PFS of 10.0 months $(95 \% \mathrm{Cl}: 7.6$ to 12.4 


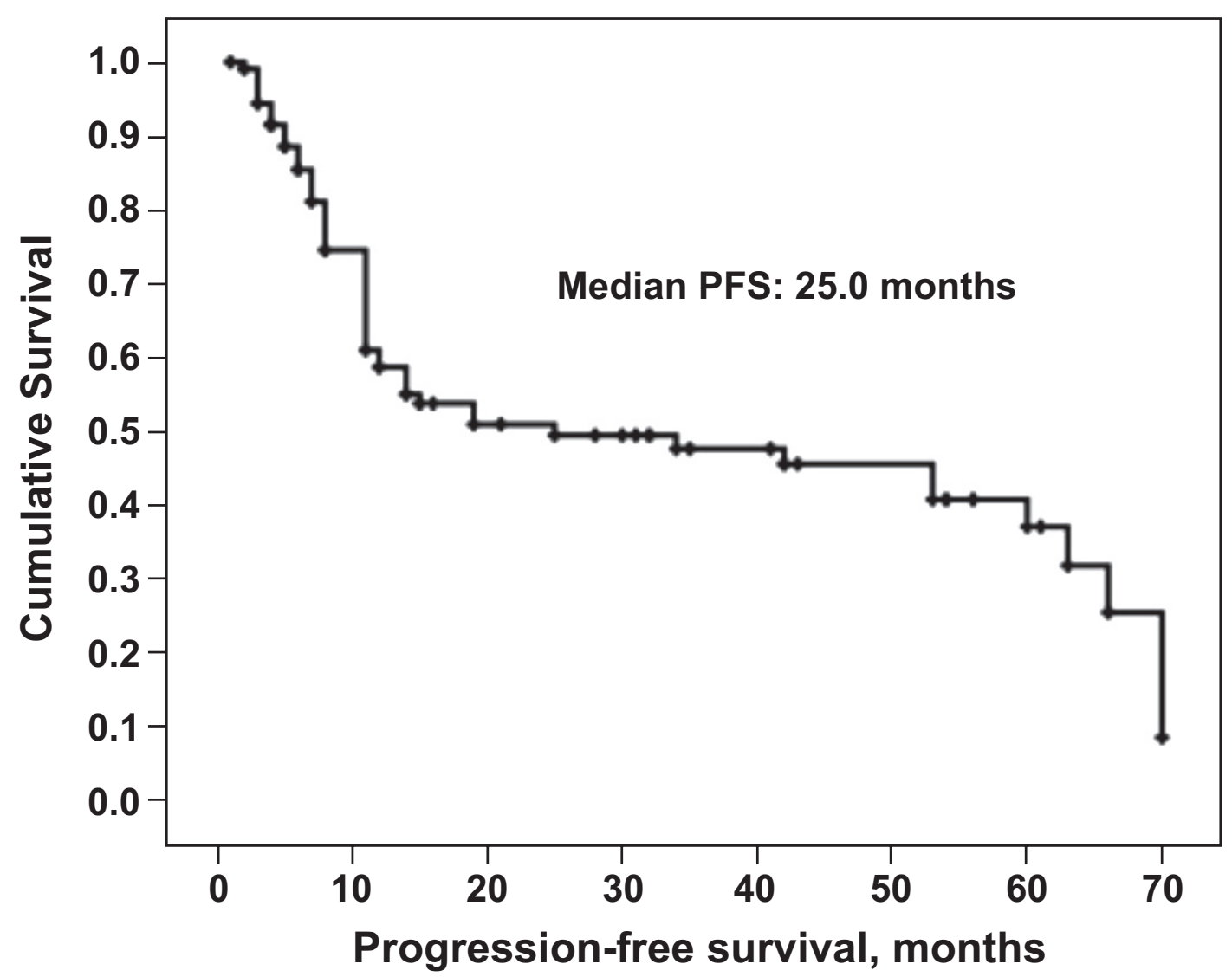

Figure 2. Progression-free survival in months of Filipino multiple myeloma patients in the USTH. Generally, the time of treatment initiation to disease progression or death is almost 2.1 years.

months) after salvage therapy with bortezomibbased regimen versus 8.3 months $(95 \% \mathrm{Cl}: 6.4$ to 10.1 months) without bortezomib (Figure 3). Using the Log Rank (Mantel-Cox) method (see Appendix $E)$, the PFS of those who underwent frontline and salvage treatments with bortezomib-based regimen was longer compared to non-bortezomib containing therapy with p-values of 0.002 and 0.049, respectively.

The median TTR (n=31) was 9.0 months (range of 3-17 months). One developed breast adenocarcinoma, one with lung mass and another had tongue squamous papilloma within six years but all were established unrelated to treatment. None of them reported long-term adverse effects to treatment such as cardiotoxicity, infertility and pulmonary fibrosis.

\section{DISCUSSION}

MM is one of the most common hematologic malignancies in which the incidence increases with age and varies by ethnicity, with Asians showing relatively lower incidence than Caucasians.[12]
However, recent reports have exposed increased morbidity in Asia.[13] This six-year retrospective analysis from a single local institution revealed representative insights into the updated clinical demographics and real-world practical treatment patterns as well as outcomes in patients with symptomatic MM in a developing third world country like the Philippines.

The collated results from our institution is at par with the data from the large Asian Myeloma Network (AMN) Study involving seven countries (China, Hong Kong, Japan, Korea, Singapore, Taiwan and Thailand) from 1986 to 2011.[13] The median age of diagnosis at 61 years old, median hemoglobin of $<10 \mathrm{~g} / \mathrm{dL}$, median creatinine of $<2.0 \mathrm{mg} / \mathrm{dL}$, median ionized calcium of $<10.5 \mathrm{mg} / \mathrm{dL}$ (or 2.62 $\mathrm{mmol} / \mathrm{L}$ ), and detection of lytic bone lesions at the time of diagnosis were all comparable. The presence of bone involvement at diagnosis correlated to the bulk of patients with initial clinical presentation of a dull backbone or body pains. Though only a limited number of patients were able to afford, the profile of serum heavy chain type ( $\mathrm{gG}$ ) and IPSS parameters (stage III) were also similar with the rest 

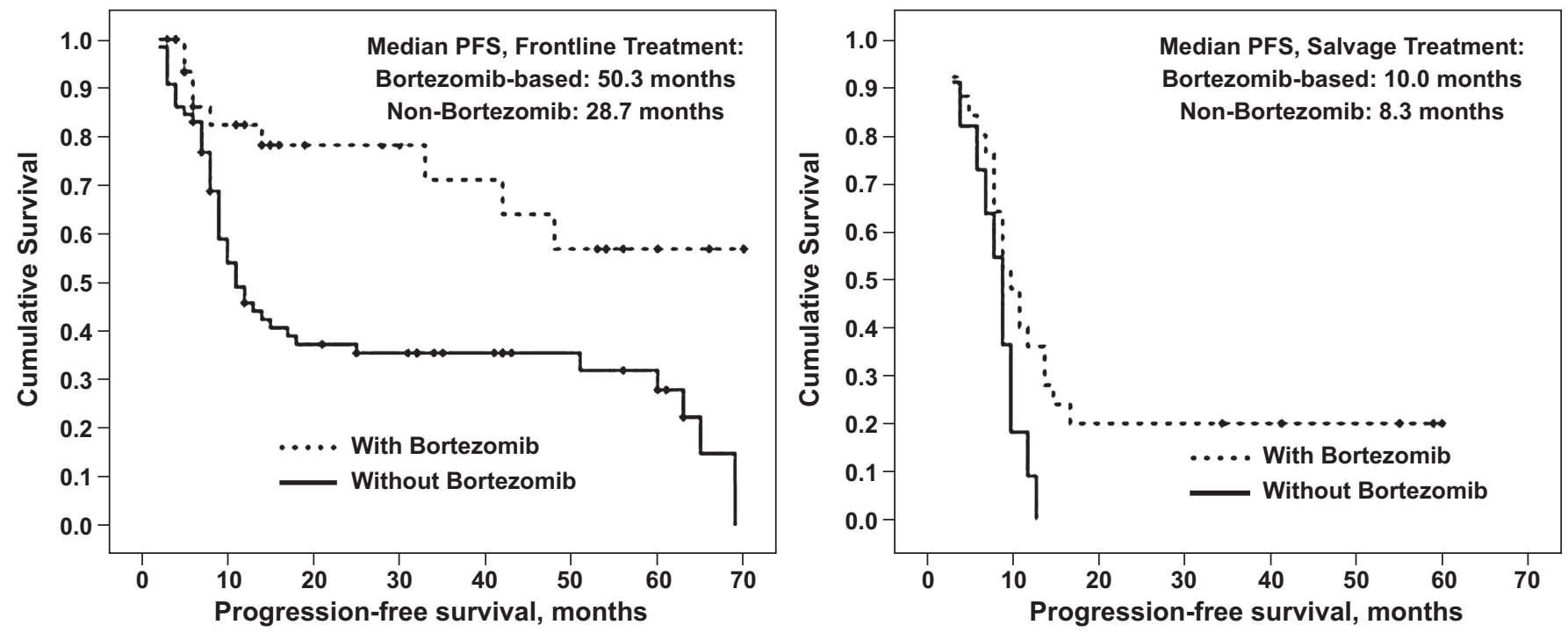

Figure 3. Progression-free survival in months of Filipino multiple myeloma patients in the USTH after frontline (left) versus salvage (right) treatments with bortezomib-based regimen versus non-bortezomib containing therapy. This clearly showed a two-fold increase in PFS of bortezomib-containing frontline regimen group (left) versus non-bortezomib. There is also a difference of two months in the PFS bortezomib-based salvage therapy (right) versus non-bortezomib.

of Asia. Due to the minimum number of parameters required for staging, its simplicity and better prognostication, Thomasian clinicians prefer IPSS than the Durie-Salmon System. Females were slightly affected than males (ratio 1.1:1) in contrast to the male predominance established in international demographics. FISH and cytogenetics data were scarce due to its high cost, though those who were able to comply mostly belonged to the standard risk. In our setting, clinicians and patients would rather allocate resources to treatment than do special tests, especially if the diagnosis is already definite by bone marrow morphology. Aside from that, the detection sensitivity of interphase FISH is limited by the percentage of plasma cells in the entire bone marrow and metaphase cytogenetic analysis often fails to identify genomic abnormalities due to the low proliferation rate of plasma cells. [14] Detection of cytogenetic abnormalities was prioritized in PD or relapsed/refractory cases, but still only a few were able to comply due to lack of adequate funds. Five patients were documented to have high risk features $[\mathrm{t}(4 ; 14)$ or $\mathrm{t}(14 ; 16), 17 \mathrm{p} 13 \mathrm{del}$ and/or $1 \mathrm{q} 21$ gain] and all of them went into PD.

Our patients' median hemoglobin level corresponded to the WHO mild anemia grading, which was observed to be the most common laboratory presentation and reason for hematologic referral, some even incidental finding. The estimated median eGFR using CKD-EPI $(\sim 52.4 \mathrm{~mL} / \mathrm{min})$ of patients included were not hemodialysis-requiring upon diagnosis, though as of the time of writing there are three patients ongoing renal replacement therapy.

Since myeloma is primarily a disease of the elderly, $66 \%$ were already unemployed or had already retired at the time of diagnosis, with almost one-third exposed to farming, an occupational risk factor of statistically high prevalence in myeloma.[15] As expected, those having multiple comorbidities seem to resist desirable treatment response as early as induction.

As soon as the diagnosis was confirmed at least by the characteristic bone marrow morphology, treatment was immediately administered either by single or dual oral regimen making the time of diagnosis same as time of treatment. Due to financial challenges, all patients were managed only pharmacologically. However, because of the recent various assistance programs for autologous bone marrow transplantation locally, we have already referred a number of qualified and fit patients, yet none of them underwent the procedure as of date. The youngest one eligible refused due to religious beliefs (on blood transfusion).

A paradigm shift in myeloma treatment has been observed due to various newer agents now accessible and available in the country. Based on a cross-sectional analysis done by Caguioa, et al. in $2006,87 \%$ received melphalan-prednisone (MP) as 
the first line treatment.[8] Our recent data showed that only $17.3 \%$ of patients received MP, and the majority at $23.5 \%$ were given a combination of melphalan-prednisone-thalidomide (MPT) as frontline regimen, which is the same as the standard of care in Indonesia presented during the latest American Society of Hematology Highlights in Asia Convention.

Locally available novel drugs for myeloma included proteosome-inhibitor bortezomib, immuno-modulator lenalidomide and alkylating agent bendamustine. Bortezomib became commercially available in the Philippines in the year 2006 and bendamustine in 2017. Lenalidomide was introduced to the country in 2006, but our patients currently avail it through compassionate use only. Of these three, bortezomib was the one of increased utility not just as a part of the salvage chemotherapeutic regimen, but also in the frontline setting (cumulative rate of $35.7 \%$, higher compared to that of the Asian Myeloma Network Study at 19.1\%).[13] Steroids were still used but the frequency decreased as the line of treatment proceeded, mainly due to its undesirable effects on chronic exposure. Patients on lenalidomide had persistent grade 2-3 neutropenia on treatment.

A total of $18.4 \%$ of our myeloma patients achieved CR after frontline treatment - more than seven-fold increase compared to $2.5 \% \mathrm{CR}$ rate from the same 2006 local study. Out of those who achieved CR after induction, $66.7 \%$ were given bortezomib-based chemotherapy regimen. VGPR was attained by $13.3 \%$, of which $71.4 \%$ received bortezomib as part of their frontline treatment. The results of combined deep responses (CR+VGPR) of our patients at $31.7 \%$ was higher than that of the Asian Myeloma Network Study[13] at 30.9\%. Compared to the Indonesian data[16] in which CR rate after primary chemotherapy was at $8.67 \%$, our results were way beyond better.

Because of its cost and limited availability through charity or access programs, Thomasian clinicians practice "bortezomib-sharing" amongst their myeloma patients, making almost all of our patients on bortezomib-based therapy receive the drug on their treatment schedule using their available stocks. Rather than discarding the excess, it is still being shared to another for free laware that the dose is not optimal). It could not be denied that this practice helped a lot of MM patients on bortezomib achieve a desirable, sustainable response.
The median OS of Filipino myeloma patients in our institution for six years was 49.5 months (95\% Cl 42.7-56.2) which was equivalent to 4.1 years, comparable to that of the AMN study[13] with median $\mathrm{OS}$ at 47 months $(95 \% \mathrm{Cl} 44.0-50.0)$ and to the survival analysis of Indonesia[16] at 47 months also.

The median PFS of the participants was 25.0 months (95\% Cl3-50.8). With respect to treatment, the median PFS of both bortezomib-containing induction (50.3 months, 95\% Cl 39.8-6.7) and salvage (10.0 months, $95 \% \mathrm{Cl} 7.6-12.4)$ therapies were higher than those of a non-bortezomib based regimen. Repeated use of this agent in new combinations still achieved clinical benefit for most of our patients; however, PFS was noticeably longer during the first use of the drug and became progressively shorter with each subsequent regimen containing it. This observation can be attributed to the fact that patients who technically progress have disease-related highrisk features making them poorly responsive or even refractory to bortezomib. Yet, our median PFS results were significantly higher than that of a Caucasian 2016 study published, wherein median PFS for patients treated with frontline therapy including bortezomib-treated patients was 13.8 months and only 4.0 months for those receiving this proteosomeinhibitor as part of a salvage therapy. [11] The December 2018 published 10-year results of the GIMEMA-MMY-3006 Trial have shown benefits of combination bortezomib in patients diagnosed with $M M$, even those predicted to have adverse prognosis based on high-risk cytogenetic abnormalities, IPSS, and/or failure to achieve CR to therapy.[17]

The median time to relapse of Filipino myeloma patients in our institution was 9.0 months (range 3-17 months), earlier compared to the progression time from a Korean perspective at 13 months.[18] Though most patients did not comply with all the stringent laboratories to earlier detect biochemical relapse due to financial challenges, most of them came on a tight follow-up schedule. Understanding the non-curative nature of $M M$ and the limited set of treatment available in our setting as of the moment, patients' commitment to strict follow-up schedule contributed significantly to the desirable results of this study. Patients did have early detection of clinical relapse and prevention of complications, and early death. This meticulous attitude and high index of suspicion of our clinicians were contributory not 
just to the early detection of clinical relapse but to increasing myeloma incidence in our institution as well.

\section{CONCLUSION}

This local retrospective analysis demonstrated the paradigm shift in the treatment modality of MM compared to 12 years ago, and the survival outcomes that has significantly improved, especially on best response to chemotherapy. Short of the ideal management in a third world country like the Philippines, we can now set our own standard of care based on the treatments available including novel agents like bortezomib and the best practices that our institution offers.

\section{Conflict of Interest}

The authors do not have any conflict of interest and have nothing to disclose. 


\section{REFERENCES}

1. Kaushansky K, Lichtman MA, Prchal JT, Levi MM, Press OW, Burns L, et al. Williams Hematology, 9th ed. 2016. p. 1733-61.

2. Kumar SK, Callander NS, Alsina M, Atanackovic D, Biermann JS, Chandler JC, et al. Multiple myeloma, version 3.2017, NCCN Clinical Practice Guidelines in Oncology. J Natl Compr Canc Netw [Internet]. 2017 Feb; 15(2):23069. Available from: http://dx.doi.org/10.6004/ inccn.2017.0023

3. Criteria for the classification of monoclonal gammopathies, multiple myeloma and related disorders: a report of the International Myeloma Working Group. Br J Haematol. 2003 Jun; 121 (5):749-57.

4. Durie BG, Salmon SE. A clinical staging system for multiple myeloma. Correlation of measured myeloma cell mass with presenting clinical features, response to treatment, and survival. Cancer. 1975 Sep;36(3):842-54.

5. Greipp PR, Miguel JS, Durie BGM, Crowley JJ, Barlogie $B$, Bladé J, et al. International staging system for multiple myeloma. JCO [Internet]. 2005 May 20;23(15):341220. Available from: http://dx.doi.org/10.1200/ JCO.2005.04.242

6. Gandolfi S, Prada CP, Richardson PG. How I treat the young patient with multiple myeloma. Blood [Internet]. 2018 Sep 13;132(11):1114-24. Available from: http:// dx.doi.org/10.1182/blood-2017-05-693606

7. San Miguel JF, Schlag R, Khuageva NK, Dimopoulos MA, Shpilberg $O$, Kropff $M$, et al. Persistent overall survival benefit and no increased risk of second malignancies with bortezomib-melphalan-prednisone versus melphalan-prednisone in patients with previously untreated multiple myeloma. JCO [Internet]. 2013 Feb 1;31(4):448-55. Available from: http://dx.doi.org/10.1200/JCO.2012.41.6180

8. Caguioa PB, Natino DF, Torres R, et al. The Philippine Multiple Myeloma Registry, 2006. Archived at the Philippine Society of Hematology and Blood Transfusion.

9. Palumbo A, Rajkumar SV, San Miguel JF, Larocca A, Niesvizky R, Morgan G, et al. International Myeloma Working Group Consensus Statement for the management, treatment, and supportive care of patients with myeloma not eligible for standard autologous stem-cell transplantation. JCO [Internet]. 2014 Feb 20;32(6):587-600. Available from: http://dx.doi.org/10.1200/JCO.2013.48.7934

10. $\mathrm{NCl}$ dictionary of cancer terms [Internet]. National Cancer Institute. 2021 [cited 1 March 2019]. Available from: https://www.cancer.gov/publications/dictionaries/ cancer-terms

11. Berenson A, Vardanyan S, David M, Wang J, Harutyunyan NM, Gottlieb J, et al. Outcomes of multiple myeloma patients receiving bortezomib, lenalidomide, and carfilzomib. Ann Hematol [Internet]. 2016 Dec 8;96(3):449-59. Available from: http://dx.doi.org/10.1007/s00277-016-2889-2
12. Torre LA, Bray F, Siegel RL, Ferlay J, Lortet-Tieulent J, Jemal A. Global cancer statistics, 2012. CA: A Cancer Journal for Clinicians [Internet]. 2015 Feb 4;65(2):87-108. Available from: http://dx.doi.org/10.3322/caac.21262

13. Kim K, Lee JH, Kim JS, Min CK, Yoon SS, Shimizu K, et al. Clinical profiles of multiple myeloma in Asia-an Asian myeloma network study. Am J Hematol. [Internet]. 2014 Apr 26;89(7):751-6. Available from: http://dx.doi. org/10.1002/ajh.23731

14. Fonseca R, Barlogie B, Bataille R, Bastard C, Bergsagel PL, Chesi $M$, et al. Genetics and cytogenetics of multiple myeloma. Cancer Res [Internet]. 2004 Feb 15;64(4): 1546-58. Available from: http://dx.doi.org/10.1158/0008-5472. can-03-2876

15. Kalita LK, Mondol M, Gogoi PK, SarmaUCh. Distribution of different occupations in multiple myeloma patients- a hospital based study at a tertiary care hospital, Guwahati, Assam, India. Int J Res Med Sci [Internet]. 2017 Apr 26;5(5):2156. Available from: http://dx.doi.org/10.18203/23206012 .ijrms20171861

16. The Global Cancer Observatory. [online] Available at: <http://gco.iarc.fr/today/data/factsheets/ populations/360-indonesia-fact-sheets.pdf>. January 2019.

17. Christina L. Bortezomib added to SoC improves 10-year survival in newly diagnosed multiple myeloma. December 20, 2018. Tacchetti P, et al, ASH 2018, abstract 125.

18. Hong J, Lee JH. Recent advances in multiple myeloma: a Korean perspective. Korean J Intern Med [Internet]. 2016 Sep 1;31(5):820-34. Available from: http://dx.doi. org/10.3904/kjim.2015.408

19. Rajkumar SV, Harousseau J-L, Durie B, Anderson KC, Dimopoulos $M$, Kyle $R$, et al. Consensus recommendations for the uniform reporting of clinical trials: report of the International Myeloma Workshop Consensus Panel 1. Blood [Internet]. 2011 May 5;117(18):4691-5. Available from: http://dx.doi.org/10.1182/blood-2010-10-299487

(i) Open Access This article is licensed under a Creative Commons Attribution 4.0 International License, which permits use, sharing, adaptation, distribution and reproduction in any medium or format, as long as you give appropriate credit to the original author(s) and the source, provide a link to the Creative Commons license, and indicate if changes were made. The images or other third party material in this article are included in the article's Creative Commons license, unless indicated otherwise in a credit line to the material. If material is not included in the article's Creative Commons license and your intended use is not permitted by statutory regulation or exceeds the permitted use, you will need to obtain permission directly from the copyright holder. To view a copy of this license, visit http://creativecommons.org/licenses/by/4.0/. 


\section{APPENDICES}

\section{Appendix A. Criteria for Diagnosis of Multiple Myeloma}

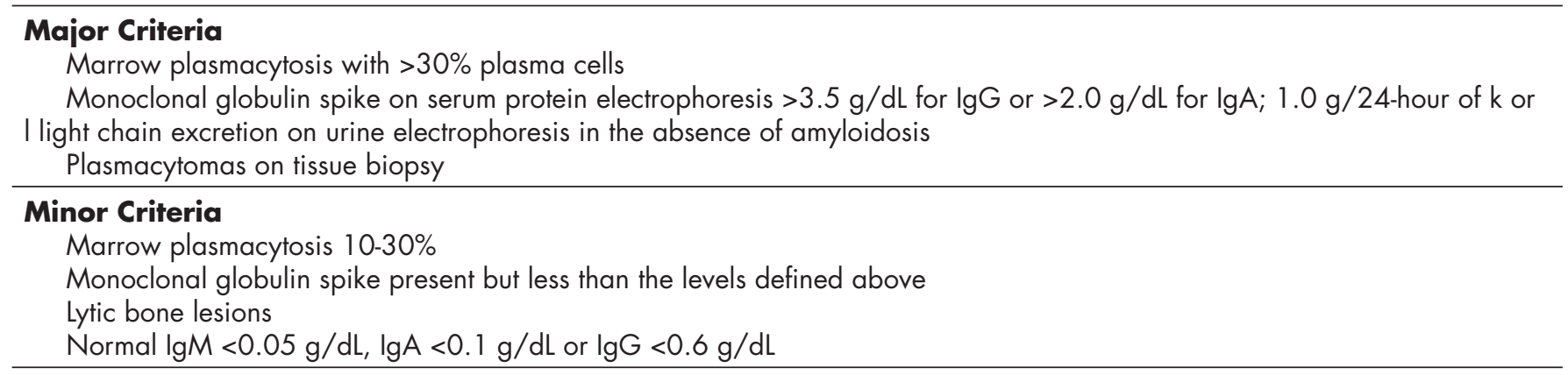

The diagnosis of plasma cell myeloma is confirmed when at least one major and one minor criterion or at least three minor criteria are documented in symptomatic patients with progressive disease.

The presence of features not specific for the disease, such as the following, supports the diagnosis, particularly if of recent onset: anemia, hypercalcemia, azotemia, bone demineralization, or hypoalbuminemia.

\section{Appendix B. Staging Systems for Multiple Myeloma}

\begin{tabular}{|c|c|c|}
\hline Stage & Durie-Salmon System & $\begin{array}{l}\text { International Prognostic } \\
\text { Staging System (IPSS) }\end{array}$ \\
\hline $\mathbf{I}$ & $\begin{array}{l}\text { All of the following: } \\
\text { - Hemoglobin value }>10 \mathrm{~g} / \mathrm{dL} \\
\text { - Serum calcium normal or }<12 \mathrm{~g} / \mathrm{dL} \\
\text { - Bone x-ray, normal bone structure, or solitary bone } \\
\text { plasmacytoma only } \\
\text { - Low M-component production rate: } \\
\text { - } \operatorname{lgG} \text { value }<5 \mathrm{~g} / \mathrm{dL} \\
\text { - } \text { IgA value }<3 \mathrm{~g} / \mathrm{dL} \\
\text { - Bence Jones protein }<4 \mathrm{~g} / 24 \mathrm{~h}\end{array}$ & $\begin{array}{l}\text { Serum b-2 microglobulin } \\
<3.5 \mathrm{mg} / \mathrm{L} \\
\text { Serum albumin }{ }^{3} 3.5 \mathrm{~g} / \mathrm{dL}\end{array}$ \\
\hline II & Neither stage I nor stage III & Neither stage I nor stage III \\
\hline III & $\begin{array}{l}\text { One or more of the following: } \\
\text { - Hemoglobin value }<8.5 \mathrm{~g} / \mathrm{dL} \\
\text { - Serum calcium value }>12 \mathrm{mg} / \mathrm{dL} \\
\text { - Advanced lytic bone lesions } \\
\text { - High M-component production rate } \\
\text { - } \lg G \text { value }>7 \mathrm{~g} / \mathrm{dL} \\
\text { - } \operatorname{lgA} \text { value }>5 \mathrm{~g} / \mathrm{dL} \\
\text { - Bence Jones protein }>12 \mathrm{~g} / 24 \mathrm{~h}\end{array}$ & $\begin{array}{l}\text { Serum b-2 microglobulin } 5.5 \\
\mathrm{mg} / \mathrm{L}\end{array}$ \\
\hline
\end{tabular}

\section{Sub-classification Criteria}

A Normal renal function (serum creatinine $<2 \mathrm{mg} / \mathrm{dL}$ )

B Abnormal renal function (serum creatinine $2 \mathrm{mg} / \mathrm{dL}$ ) 


\section{Appendix C. Response Criteria for Multiple Myeloma}

\begin{tabular}{|c|c|}
\hline Response & Criteria \\
\hline \multirow[t]{5}{*}{ Complete Response (CR) } & Negative immunofixation of serum and urine \\
\hline & Disappearance of any soft tissue plasmacytomas \\
\hline & $<5 \%$ plasma cells in the bone marrow \\
\hline & $\begin{array}{l}\text { In patients for whom only measurable disease is by serum FLC level, normal FLC ratio of } \\
0.26 \text { to } 1.65 \text { in addition to CR criteria is required }\end{array}$ \\
\hline & -2 consecutive assessments are needed \\
\hline \multirow[t]{3}{*}{$\begin{array}{l}\text { Very Good Partial } \\
\text { Response (VGPR) }\end{array}$} & $\begin{array}{l}\text { Serum and urine } M \text { component detectable by immunofixation but not on electrophoresis or } \\
90 \% \text { reduction in serum } M \text { component plus urine } M \text { component }<100 \mathrm{mg} / 24 \mathrm{~h}\end{array}$ \\
\hline & $\begin{array}{l}\text { In patients for whom only measurable disease is by serum } \mathrm{FLC} \text { level, }>90 \% \text { decrease in } \\
\text { difference between involved and uninvolved FLC levels, in addition to VGPR criteria, is } \\
\text { required }\end{array}$ \\
\hline & -2 consecutive assessments are needed \\
\hline \multirow[t]{5}{*}{ Partial Response (PR) } & $\begin{array}{l}50 \% \text { reduction of serum } M \text { protein and reduction in } 24 \text {-hour urinary } M \text { protein by } 90 \% \text { or to } \\
<200 \mathrm{mg} / 24 \mathrm{~h}\end{array}$ \\
\hline & $\begin{array}{l}\text { If serum and urine } M \text { protein are not measurable, } 50 \% \text { decrease in difference between } \\
\text { involved and uninvolved FLC levels is required in place of } M \text { protein criteria }\end{array}$ \\
\hline & $\begin{array}{l}\text { If serum and urine } \mathrm{M} \text { protein and serum } \mathrm{FLC} \text { assay are not measurable, } 50 \% \text { reduction in } \\
\text { bone marrow plasma cells is required in place of } M \text { protein, provided baseline percentage } \\
\text { was } 30 \%\end{array}$ \\
\hline & $\begin{array}{l}\text { In addition, if present at baseline, } 50 \% \text { reduction in size of soft tissue plasmacytomas is } \\
\text { required }\end{array}$ \\
\hline & $\begin{array}{l}-2 \text { consecutive assessments are needed; no known evidence of progressive or new bone } \\
\text { lesions if radiographic studies were performed }\end{array}$ \\
\hline
\end{tabular}

Stable Disease (SD)

Not meeting criteria for CR, VGPR, PR or PD

No known evidence of progressive or new bone lesions if radiographic studies were performed

Progressive Disease (PD) Increase of 25\% from lowest response value in any of following:

Serum $M$ component with absolute increase of $0.5 \mathrm{~g} / \mathrm{dL}$; serum $M$ component increases of 1 $\mathrm{g} / \mathrm{dL}$ are sufficient to define relapse if starting $M$ component is $5 \mathrm{~g} / \mathrm{dL}$ and/or

Urine $M$ component (absolute increase must be $200 \mathrm{mg} / 24 \mathrm{~h}$ ) and/or;

Only in patients without measurable serum and urine $M$ protein levels: difference between involved and uninvolved FLC levels (absolute increase must be $>10 \mathrm{mg} / \mathrm{dL}$ );

Only in patients without measurable serum and urine $M$ protein levels and without measurable disease by FLC level, bone marrow plasma cell percentage (absolute percentage must be 10\%)

Development of new or definite increase in size of existing bone lesions or soft tissue plasmacytomas

Development of hypercalcemia that can be attributed solely to plasma cell proliferative disorder

-2 consecutive assessments before new therapy are needed 


\section{Appendix D. Data Collection Forms \\ DATA COLLECTION FORM}

\begin{tabular}{|c|c|c|}
\hline Patient Identifier & \multicolumn{2}{|l|}{ Date } \\
\hline Occupation & Age & Gender \\
\hline Province of Residence: & \multicolumn{2}{|c|}{$\begin{array}{l}\text { Highest Educational Attainment: } \\
\text { elementary } \\
\text { high school } \\
\text { college } \\
\text { post-graduate studies } \\
\text { doctoral degree } \\
\text { no formal education }\end{array}$} \\
\hline \multirow{2}{*}{$\begin{array}{l}\text { Comorbid Illness: } \\
\text { Hypertension } \\
\text { Diabetes mellitus } \\
\text { Coronary Artery Disease } \\
\text { Congestive Heart Failure } \\
\text { Bronchial Asthma } \\
\text { Chronic Kidney Disease } \\
\text { COPD } \\
\text { Chronic Liver Disease } \\
\text { Hepatitis } \\
\text { Others (specify): } \\
\text { (Multiple Answers) }\end{array}$} & \multicolumn{2}{|c|}{ Medications: } \\
\hline & \multicolumn{2}{|c|}{$\begin{array}{l}\text { Past Medical History: } \\
\text { Previous surgery } \\
\text { Previous hospitalization }\end{array}$} \\
\hline $\begin{array}{l}\text { Associated symptoms: } \\
\text { weight loss } \\
\text { palpable lymph node } \\
\text { easy fatigability } \\
\text { back pain } \\
\text { Others (specify): } \\
\text { (Multiple Answers) }\end{array}$ & \multicolumn{2}{|c|}{ Date of Diagnosis: } \\
\hline BMA result: & \multicolumn{2}{|c|}{ SPEP: } \\
\hline 邓2 microglobulin: & \multicolumn{2}{|c|}{ Creatinine: } \\
\hline $\mathrm{LDH}:$ & \multicolumn{2}{|c|}{ Cytogenetics: } \\
\hline $\begin{array}{l}\text { Stage of Disease (R-ISS) } \\
\text { Stage I } \\
\text { Stage II } \\
\text { Stage III }\end{array}$ & \multicolumn{2}{|c|}{ Date of Treatment Initiation: } \\
\hline $\begin{array}{l}\text { BMT } \\
\text { Yes } \\
\text { No }\end{array}$ & \multicolumn{2}{|c|}{$\begin{array}{l}\text { Bisphosphonate: } \\
\text { Zoledronic acid } \\
\text { Pamidronate } \\
\text { None } \\
\text { Others: }\end{array}$} \\
\hline
\end{tabular}




\begin{tabular}{|c|c|}
\hline $\begin{array}{l}\text { Induction Chemotherapy: } \\
\text { Melphalan-Prednisone } \\
\text { Bortezomib MP } \\
\text { Bortezomib-Dexamethasone } \\
\text { Thalidomide-Dexamethasone } \\
\text { Bortezomib-Thal-Dex } \\
\text { Dexamethasone } \\
\text { Thal-Mel-Prednisone }\end{array}$ & $\begin{array}{l}\text { Maintenance Therapy: } \\
\text { Thalidomide } \\
\text { Lenalidomide } \\
\text { Bortezomib } \\
\text { Dexamethasone } \\
\text { None } \\
\text { Others: }\end{array}$ \\
\hline $\begin{array}{l}\text { VAD } \\
\text { Others (specify) }\end{array}$ & $\begin{array}{c}\text { Radiotherapy: } \\
\text { Yes } \\
\text { No }\end{array}$ \\
\hline Duration of Induction Chemotherapy: & Duration of Maintenance Therapy: \\
\hline
\end{tabular}

\section{Treatment Outcome}

\begin{tabular}{|c|c|}
\hline \multirow{2}{*}{\begin{tabular}{|l} 
Tumor Response: \\
Complete Response \\
Partial Response \\
Very Good PR \\
Stable Disease \\
Progressive Disease
\end{tabular}} & Date of relapse: \\
\hline & Date of initiation of $2^{\text {nd }}$ line treatment: \\
\hline $2^{\text {nd }}$ line chemotherapy: & $\begin{array}{r}\text { BMT } \\
\text { Yes } \\
\text { No }\end{array}$ \\
\hline $\begin{array}{l}\text { Response to } 2^{\text {nd }} \text { line treatment: } \\
\text { Complete Response } \\
\text { Partial Response } \\
\text { Very Good PR } \\
\text { Stable Disease } \\
\text { Progressive Disease }\end{array}$ & $\begin{array}{c}3^{\text {rd }} \text { line of treatment: } \\
\text { Yes } \\
\text { No }\end{array}$ \\
\hline \multirow[t]{2}{*}{$\begin{array}{c}\text { Response to } 3^{\text {rd }} \text { line treatment: } \\
\text { Complete Response } \\
\text { Partial Response } \\
\text { Very Good PR } \\
\text { Stable Disease } \\
\text { Progressive Disease }\end{array}$} & $\begin{array}{c}2^{\text {nd }} \text { primary tumor: } \\
\text { Yes } \\
\text { No }\end{array}$ \\
\hline & Site of $2^{\text {nd }}$ primary tumor: \\
\hline \multirow{2}{*}{$\begin{array}{l}\text { Other long term side effects: } \\
\text { cardiotoxicity } \\
\text { pulmonary fibrosis } \\
\text { infertility } \\
\text { others: } \\
\text { (Multiple Answers) }\end{array}$} & Date of Death: \\
\hline & Cause of Death: \\
\hline
\end{tabular}




\section{Appendix E}

Comparison of Survival Using Bortezomib as the Frontline Treatment

\begin{tabular}{lcccc}
\hline & Overall Comparisons & & & \\
\hline & Chi-Square & df & Sig. \\
Log Rank (Mantel-Cox) & 9.600 & 1 & .002 \\
Breslow (Generalized Wilcoxon) & 7.966 & 1 & .005 \\
Tarone-Ware & 8.732 & 1 & .003 \\
\hline
\end{tabular}

Test of equality of survival distributions for the different levels of frontline bortezomib

At alpha $=5 \%$, PFS of group [1 1] (50.3) is greater than that of group [10] (28.7) since p-value $=0.002$.

Comparison of Survival of Using Bortezomib for the Salvage Treatment

\begin{tabular}{lcccc}
\hline & Overall Comparisons & & & \\
\hline & & Chi-Square & df & Sig. \\
Log Rank (Mantel-Cox) & 3.785 & 1 & .049 \\
Breslow (Generalized Wilcoxon) & 1.915 & 1 & .166 \\
Tarone-Ware & 2.689 & 1 & .101 \\
\hline
\end{tabular}

Test of equality of survival distributions for the different levels of salvage bortezomib

At alpha $=5 \%$, PFS of group [21] is significantly different from that of group [20] since p-value $=0.049$. 